ELORE (ISSN 1456-3010), vol. 15 - 1/2008.

Julkaisija: Suomen Kansantietouden Tutkijain Seura ry.

[http://www.elore.fi/arkisto/1_08/aar1_08.pdf]

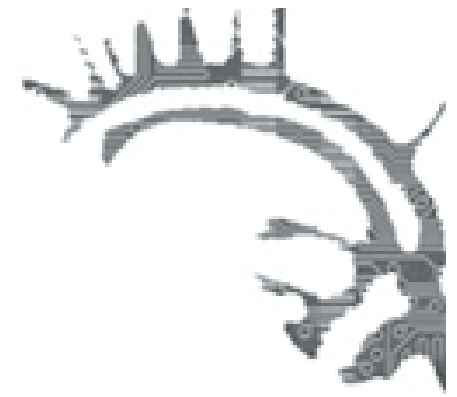

\title{
Ajankohtaista: \\ TURUN LINNA KERROTTUNA JA KERTOVANA TILANA
}

Lectio praecursoria Helsingin yliopistossa 15.3.2008.

\section{Petja Aarnipuu}

Zahcris Topelius luonnosteli Suomen Turkua kirjassaan Matkustus Suomessa vuonna 1873 seuraavaan tapaan:

\begin{abstract}
Nämät kolme - linna, kirkko, joki - ovat ilmi-eläviä muistoja valtiollisesta vallasta, hengellisestä elinvoimasta ja sivistyksen virrasta. Seitsemän vuosisataa on tässä edessämme näillä rannoilla. Linna puhuu vielä ristiretkistä, kirkko romalaisen pappisvallan suuruudesta, ja Aura, vaikka Suomen vähimpiä jokia, on vakonut leveän väylän vuosisatojen läpi. (Topelius 1984, 62.)
\end{abstract}

Nämät kolme - Turun linna, Turun tuomiokirkko ja Aurajoki - ovat Turun kaupunkikuvan keskeisiä rakennuspuita yhä edelleen. Niin opaskirjoissa kuin kaupungin strategiateksteissäkin niiden varaan rakennetaan Turun kulttuurinen perusta: pitkä historia, joka yhtäältä tekee Turusta ainutlaatuisen suomalaisten kaupunkien joukossa ja toisaalta liittää sen keskiaikaisten eurooppalaisten kaupunkien joukkoon.

\section{RAKENNUSMONUMENTTI, TILA, MUISTI JA MUISTUTTAMINEN}

Turun linna, jonka valitsin väitöstutkimukseni kohteeksi, on rakennusmonumentti. Monumentaalisuuteen liittyy ajatus muistamisesta, mutta myös muistuttamisesta. Olen tutkimuksessani paneutunut erityisesti selvittämään, minkälaisten asioiden muistomerkki Turun linna nykyään on, eli mitä linnassa muistetaan ja mistä muistutetaan ja millä keinoilla muistaminen ja muistuttaminen tapahtuvat. 


\section{TURUN LINNA KERROTTUNA JA KERTOVANA TILANA}

On selvää, että Turun linna on nimenomaan historiallinen rakennusmonumentti: siellä ajatukset suuntautuvat vuosisatojen taa. Tutkimukseni ajallinen pääpaino on kuitenkin nykyajassa ja lähihistoriassa. Väitöskirjani kannessa on ilmakuva Turun linnasta nykyisessä ympäristössään. Se on rajaus vielä laajemmasta kuvasta, joka muistuttaa jo piilokuvaa - missä on keskiaikainen Turun linna? Kun linnaa alettiin rakentaa 1200-luvun lopulla, sen tonttina oli kallioluoto. Luoto liittyi maannousun myötä mantereeseen, mutta nykyisin linna sijaitsee vihreällä saarekkeella, jota rajaavat Aurajoen lisäksi satama- ja teollisuusalueet.

Olenkin lähestynyt Turun linnaa elettynä ja koettuna tilana, jossa erilaiset ajallisuudet kiinnittyvät sijainnilliseen paikkaan. Aika ja paikka kehkeytyvät tilaksi toiminnan kautta, ja toimintaa Turun linnassa taas määrittävät ne arkkitehtoniset puitteet, jotka sille on annettu rakennus- ja restaurointiprojekteissa kaikkina näinä kuluneina vuosisatoina. Keskiajalla Turun linna oli ensisijaisesti puolustuslinna, sittemmin siitä tuli asuinlinna ja renessanssipalatsi. 1600-luvulla linnan hallinnollinen merkitys alkoi vähentyä. Linnan vanha pääosa paloi, ja se korjattiin varastoksi. Virastot siirrettiin esilinnaan, josta alettiin puhua "uutena linnana". 1700-luvulla Turun linnassa varastoitiin vankeja, viljaa ja sotakalustoa. Rakennukset rapistuivat, ja aikalaiset olivatkin varmoja koko linnan vähittäisestä tuhoutumisesta. Esimerkiksi linnanpastori Eric Lennqvistin tulevaisuudennäky vuonna 1764 oli seuraava:

Mutta niin on tämäkin linna, joka neljänsadan vuoden ajan on ollut suurmiesten ja hallitsijoiden residenssi, jätetty asumattomaksi; nyt siellä oleskelee vain linnan vahtimestari ja joitakin kurjia vankeja vartijoineen. Näin ollen se ei voi muuta kuin päivä päivältä rappeutua ja kallistua siihen kohtaloon, joka on aikaisemmin koitunut muiden kuuluisien linnojen osaksi. (Lennqvist 1885, 182. Suom. PA)

Vasta 1800-luvun lopulla muutoksen suunta vähitellen kääntyi, ja linnaa alettiin restauroida uuteen - eli vanhaan - loistoonsa.

\section{TURUN LINNAN RESTAUROINTI}

Oman tutkimustyöni kannalta keskeinen aikakausi on 1900-luku. Tuolloin tehtiin kauaskantoisia ratkaisuja Turun linnan tulevaisuuden suhteen. Vuosisadan alun hiljaisen tutkimuksen ja paikallisten restaurointitöiden jälkeen arkkitehti Eric Bryggman palkattiin suunnittelemaan päälinnan kokonaisrestaurointia. Väliin tulivat kuitenkin vielä talvi- ja jatkosota. Vanhan pälinnan jo ennestäänkin huonoa tilannetta pahensi palopommi, joka poltti muun muassa sen katot. Linna jouduttiin jättämään säiden armoille lopuiksi sotavuosiksi. Sotien jälkeen linnan keskiaikainen ja renessanssinaikainen pääosa oli monin paikoin "tyhjäksi puhallettu raunio", niin kuin museonjohtaja Carl Jacob Gardberg sitä luonnehti 1960-luvulla (Gardberg 1961, 6). Mittavien restaurointitöiden jälkeen päälinna avautui yleisölle vuonna 1961. 
Kaikki Turun linnassa käyneet tietävät, että sen päälinnassa ei enää tuuli ujella tyhjien seinämuurien välissä. Nykykävijä voi kuulostella historian havinaa Keskiaikaisessa kuninkaansalissa, tai vierailla Juhana-Herttuan renessanssisaleissa kerrosta ylempänä. Kävijä näkee ja tunnistaa myös uudempaa arkkitehtuuria, vaikkapa Bryggman-salissa, joka on rakennettu 1990-luvulla päälinnan eteläsiiven ullakkokerrokseen. Aiemmin siellä oli ainoastaan kattotuoleja, jotka rakenteellisesti korvattiin betoniholveilla.

Nykyään Turun linnassa on paljon teräsbetonia. Sen avulla vahvistettiin muurien rakenteita, parannettiin paloturvallisuutta ja sidottiin koko linna tukevammin peruskallioon. Nämä toimet ovat samalla paremman rakentamisen jatkumolla niiden korjausten kanssa, joita aikaisempien vuosisatojenkin rakennusmestarit ovat tehneet. Rakenteelliset parannukset ovat kaikkina aikoina tähdänneet linnan suurempaan kestävyyteen ja tarkoituksenmukaisuuteen. Jos 1560-luvulla olisi ollut teräsbetonia, sitä olisi aivan varmasti käytetty sen uuden kerroksen rakentamiseen, jota nykyään kutsumme renessanssikerrokseksi.

Teräsbetonista on kuitenkin tehty myös esimerkiksi juuri Keskiaikaisen kuninkaansalin nykyiset holvit. Väitöskirjani sivuilla 97-98 olevissa kuvissa näkyy, miten Nunnakappelin tähtiholvi rakennettiin uudestaan 1950-luvulla. Lopputulos on entisen kaltainen ja hengeltään hyvin keskiaikainen, mutta rakenteeltaan holvi on uudenaikainen. Nunnakappelin tähtiholvi oli alun perin purettu jo 1790-luvulla. Keskiaikaisen kuninkaansalin holvien purkamisesta oli vieläkin pitempi aika: Juhana-herttua puratti ne 1560-luvulla päivittäessään vanhaa puolustuslinnaa ajanmukaisemmaksi asuinpalatsiksi. Pimeästä holvihuoneesta tuli tilavampi ja valoisampi tasakattoisena, ja sinne majoitettiin herttuan drabantteja eli henkivartijoita.

Kuten sanottua, 1950-luvulla tehtiin kauaskantoisia ratkaisuja Turun linnan tulevaisuuden suhteen. Restaurointien lähempi tarkastelu osoittaa, että ratkaisuja tehtiin myös Turun linnan menneisyyden suhteen. Rappioitumisen aika pyyhittiin pois, ja sekä keskiajan että renessanssin arkkitehtoniset huippukaudet rekonstruoitiin esiin niin, että ne ovat ensimmäistä kertaa historiassa näkyvillä yhtaikaa.

\section{MitÄ TÄSTÄ PITÄISI AJATELla? ONKo TURUN LINNA VÄÄRENNÖs?}

1970-luvulta alkaen historiantutkijat, folkloristit ja etnologit ovat analysoineet kriittisesti sellaista historian ja perinteen käyttöä, jossa aitous ja alkuperäisyys ovat vaarassa vääristyä. Siitäkin näkökulmasta Turun linnaa voisi tarkastella: jos keskiaikaiset salit on rakennettu uudestaan 1950-luvulla, ovatko ne todellisuudessa keskiaikaisia? Miten Keskiaikaisessa kuninkaansalissa voi ikivanhan pöydän osmansolmuilla koristettujen jalkojen välissä olla pistorasia?

Oma tutkimukseni sijoittuu myös tähän keskusteluun perinteiden käytöstä, historian tuotteistamisesta ja kulttuuriperinnöstä. Halusin kuitenkin ottaa askeleen eteenpäin asetelmasta, jossa aitous ja epäaitous lukitaan toisensa poissulkeviksi 


\section{TURUN LINNA KERROTTUNA JA KERTOVANA TILANA}

vaihtoehdoiksi. Hyväksyin siis, että Turun linna voi olla näkökulmasta riippuen joko "aito" tai "epäaito", ja ryhdyin pohtimaan, mihin linnan restauroijat olivat tähdänneet ja mitä he olivat saaneet aikaan.

Kävi selväksi, että Turun linnan vanhan pääosan restauroinnin tavoitteet ovat olleet kahtalaiset. Ensinnäkin se on restauroitu rakennusmuistomerkiksi, joka muistuttaa ja kertoo Suomen alueen historiasta keskiajalta lähtien. Se on historiallinen monumentti, jossa voi kulkea ja jota voi kokea kaikin aistein. Toiseksi, Turun linna ikään kuin herätettiin uudestaan eloon: sinne rakennettiin tiloja, joissa on jälleen mahdollista järjestää korkeatasoisia, jopa valtiollisia juhlia. Tämä edellytti paitsi salien restaurointia myös kokonaan uusien rakenteiden tekemistä. Uudet tilat ja elämä täytyi saada sijoitettua vanhojen muurien sisälle niiin että historialliset arvot eivät kärsisi.

Analysoin tutkimuksessani restaurointiprosessia ja sen tuloksia siten, että suhtauduin linnaan ikään kuin se olisi kerrottu kertomus. Restauroijat ovat juonentaneet linnan historiaa. Tämä on edellyttänyt heiltä sekä arkeologista ja historiallista tutkimustietopohjaa että tuon tiedollisen aineksen tulkintaa. Restauroitu linna on heidän valintojensa tulos ja ilmentää sitä, mikä on koettu arvokkaaksi ja olennaiseksi suhteessa historian tapahtumiin ja rakennustaiteeseen. Lisäksi linnaan on nykyisin sisäänrakennettuna mahdollisuus ottaa se haltuun, kiertää se ympäri ja tutustua siihen.

Monumentaalinen kivilinna on, näin nähtynä, kertovaa tilaa. Turun linnan restauroidut tilat kertovat enimmäkseen vallasväen elämästä - tai elämän puitteista - keski- ja renessanssiajalla. Lisäksi ne kertovat 1950-luvulla vallinneista restaurointiideoista. Suuressa aineellisuudessaan tämänkaltainen kerronta on luonteeltaan melko pysyvää, myös siinä mielessä, että arkkitehtoninen kerronta ei muutu kovin nopeasti. On myös kyseenalaista, avautuuko se satunnaiselle kävijälle, jolla ei ole kovin paljon aikaisempaa tietoa taide- tai yleisestä historiasta. Turun linnassa on kuitenkin tarjolla myös toisenlaista kerrontaa. Opastetuilla kierroksilla samoista saleista tulee kerrottua tilaa. Suullinen kerronta on luonteeltaan varioivaa ja tilanteen mukaan muuttuvaa.

Turun makuntamuseossa on viime vuosina kehitetty paljon erilaisia opastettuja kierroksia Turun linnaan. Peruskierroksen lisäksi tarjolla on elävöitettyjä ja teemoitettuja erikoiskierroksia. Linnaan voi tutustua esimerkiksi vankiloiden kautta, menneisyyden vankien opastamana, tai taloustyön kautta fatabuurivaimon johdolla. Oppaaksi saa myös Turun linnan tonttu-ukon Murri-kissan, linnanneidon tai narrin. He kaikki juonentavat ja siten tulkitsevat samoja arkkitehtonisia tiloja omasta näkökulmastaan. Tällä on paitsi viihteellinen myös pedagoginen merkitys. Kertojanäkökulmaa vaihtamalla vallasväen linnaa voidaan ymmärtää myös arkisen aherruksen ja nimettömäksi jääneiden, mutta linnan elämän kannalta välttämättömien ihmisten työn ja maailmankuvan kautta.

Turun linna on paitsi rakennusmuistomerkki myös yksi Turun maakuntamuseon toimipaikoista. Nykyaikaisen museotyön tavoitteeksi on museolain ensimmäisessä luvussa määritelty "ylläpitää ja vahvistaa väestön ymmärrystä kulttuuristaan, historiastaan ja ympäristöstään”. Museolaitos kuuluu yhdessä arkistojen ja kirjastojen kanssa muistiorganisaatioihin. Hallinnollisena rakenteena muistiorganisaatiot huolehtivat kansallisesta kulttuuriperinnöstä. 
Perintö onkin yksi tutkimukseni avainkäsitteistä. Se on jotakin, joka siirtyy aikaisemmilta sukupolvilta seuraaville - mutta se ei siirry itsestään. Perintöä vaalitaan tietoisesti tulevaisuutta varten. Perinnön kulloinenkin haltija voi kuluttaa tai kartuttaa sitä, käyttää hyvin tai huonosti. Perinnöstä käydään riitoja. Näiden vertauskuvallisten merkitysten kautta kulttuuriperintö näyttäytyy jonakin, joka on aktiivisen toiminnan tulosta. Se muodostuu aineellisuuksien ja aineettomuuksien, ajallisten jatkuvuuksien ja katkosten, toden ja fiktion jäsentymisestä merkityksellisiksi kokonaisuuksiksi.

Kulttuuriperintö, myös tukevan kivilinnan tapauksessa, on tulosta yksilöiden ja yhteisöjen aikojen kuluessa tekemistä valinnoista. Väitöskirjatutkimuksessani olen nostanut esiin yksilöitä ja pienyhteisöjä, joiden tulkinta Turun linnasta on vaikuttanut ratkaisevasti siihen, millaisena näemme sen. Näitä valintoja olen lähestynyt kerronnallisina valintoina ja juonennuksina sekä Turun linnaa kerrottuna ja kertovana tilana. Tällaisessa tilassa ikivanha pöytä ja pistorasia voivat olla sovussa teräsbetonista valettujen, keskiaikaisten holvikaarien alla.

\section{KirjallisuUs}

GARDBERG, C. J. 1961: Turun linna. Vanhan osan esittely. Turku: Turun kaupungin historiallinen museo.

LENNQVIST, ERIC 1885: Historisk Afhandling om Åbo Slott. - Leinberg, K. G., Bidrag till kännedomen af vairt land, samlade och utgifna af K. G. Leinberg, Professor. Vol. 1. Jyväskylä: J. Länkeläs förlag.

TOPELIUS, ZACHRIS 1984: Matkustus Suomessa. Espoo: Littera. [1873]

Aarnipuu, Petja 2008: Turun linna kerrottuna ja kertovana tilana. Suomalaisen Kirjallisunden Seuran Toimituksia 1162. Helsinki: Suomalaisen Kirjallisunden Seura.

Petja Aarnipuu (s. 1970) on ollut tutkijakoulutettavana Kulttuuristen tulkintojen tutkijakoulussa 2003-2006 ja sen jälkeen toiminut apurahatutkijana. Hän jatkaa folkloristiikan alan tutkimustöitään Suomen Kulttuurirahaston ja Suomalaisen Kirjallisuuden Seuran myöntämien apurahojen turvin. 